\title{
Effect of Chromium on High Performance Cement Mortar
}

\author{
Ravi Sanker Reddy.B ${ }^{1}$, Madhusudana Reddy . B $^{2}$ \\ ${ }^{1}$ M.Tech, Department of Civil Engineering, Sri Venkateswara University College of Engineering, \\ Tirupati, Andhra Pradesh, INDIA, batturaviii@gmail.com \\ ${ }^{2}$ Assistant Professor, Department of Civil Engineering, Sri Venkateswara University College of Engineering, \\ Tirupati, Andhra Pradesh, INDIA, srinamasa@gmail.com
}

\begin{abstract}
The effect of chromium $(\mathrm{Cr})$ present in mixing water for high performance cement mortar was experimentally evaluated. The properties investigated are setting times, soundness, compressive strength, durability aspects like acid attack, alkaline attack, sulphate attack and chloride ion penetration. High performance cement mortar specimens were cast using Chromium (Cr) spiked de-ionized water and de-ionized water for test specimens and reference as mixing waters respectively. It is observed that, the initial and final setting times of cement paste with test specimens got retarded with increase of Chromium concentration in de-ionized water. The change in expansion of cement mortar is insignificant at all concentrations of the Chromium. Very slight decrease in compressive strength was observed at low concentrations of Chromium than that of controlled cement mortar and gradually increases for remaining concentrations of chromium. The compressive strength and weight of the specimen mortar cubes immersed in acid, alkaline and sulphate solutions decreases with age. The chloride ion permeability is observed low.
\end{abstract}

Key words - Chromium (Cr), Compressive Strength, De-ionized Water, High Performance Cement Mortar (HPCM), Micro Silica, Setting Times, Soundness, Super Plasticizer (SP).

\section{INTRODUCTION}

Mechanization, increases in population and human activities are continuously generating lot of liquid and solid waste causing many environmental problems in the world. Waste water generated from industrial sector is being diverted directly into rivers and streams without proper treatment in most of the cases. Construction industry is one of the largest consumers of water. Generally, potable water is suitable as mixing water for cement concrete. Due to pollution of water bodies, availability of potable water is becoming scarce for the construction industry there by forcing it to use alternate sources of water. In this regard, industrial waste water plays an important role. Reuse and recycling of industrial waste water may be practiced to attain sustainable development of construction industry.

Heavy metals like $\mathrm{Hg}, \mathrm{Zn}, \mathrm{Pb}, \mathrm{Cu}, \mathrm{Ni}, \mathrm{Fe}$ and $\mathrm{Cr}$ showed good results with cement mortar up to concentration of $600 \mathrm{mg} / \mathrm{L}$ [1]. Non-potable water, such as treated industrial waste water, which contains heavy metals like $\mathrm{Ni}, \mathrm{Zn}, \mathrm{Hg}$, $\mathrm{Cu}, \mathrm{Cr}, \mathrm{Pb}, \mathrm{Cd}$, and $\mathrm{Fe}$ was used in making cement mortar and got satisfactorily results [2]. Concrete cast with reclaimed wastewater as mixing water did not have any adverse effect. Concrete with improved initial compressive strength could be made with reclaimed wastewater used partially or totally for the mixing water [3]. Cadmium spiked de-ionized water for the concentration of $3000 \mathrm{mg} / \mathrm{L}$ and above, setting times were significantly increased, for the concentration of $3000 \mathrm{mg} / \mathrm{L}$ and above, the compressive strength were considerably decreased, For a concentration of $2000 \mathrm{mg} / \mathrm{L}$, at early ages of 3 and 7 days, the compressive strength development was slow but for 28 days and onwards, Compressive strength development was slightly higher than that of reference specimens. The compressive strength loss in reference and test specimens was almost the same when they were immersed in magnesium sulfate solutions [4]. Retardation of the early hydration process and strength development of cement mortar is caused by presence of Heavy metals such as $\mathrm{Zn}, \mathrm{Pb}, \mathrm{Cu}$ [5]. Amount and quality of mixing water in concrete and cement mortar mix are important in determining properties of concrete and cement mortar [6].Supplementary materials like GGBS and silica fume play main role in cement replacing at different percentages [7]. It was found that the strengths of both cement mortar and cement paste increases when $15 \%$ of the cement is replaced by silica fume [8]. It was suggested the term HPC for concrete mixtures that possess the following three properties: high strength, high workability, and high durability [9]. Equivocal results that are both positive and negative results are observed in cement mortar mixed with biologically contaminated water [10]. Silica Fume added to concrete increases water demands, often requiring one additional pound of water for every pound of added Silica Fume. This is due to high surface area of silica fume. This problem can be easily overcome by using super plasticizer or HRWR [11]. In case of low concentrations, hydrochloric acid and nitric acid caused higher deterioration compared to sulfuric acid during the testing period. Sulfuric acid that 
Ravi Sanker Reddy.B et al., International Journal of Emerging Trends in Engineering Research, 8(8), August 2020, 4254 - 4261

produced the least soluble calcium salt had caused the least damage on test specimens especially in terms of both strength and weight loss [12]. It was investigated the effect of acid attack on concrete with fly ash and micro silica. 150 $\mathrm{mm}$ size concrete cubes which were cured for 28 days and immersed in water with $1 \%$ of sulfuric acid for 45 day were tested and it was reported that the loss in weight of control concrete was $2.5 \%$ where as the concrete with $15 \%$ fly ash and $7.5 \%$ micro silica showed only $1.09 \%$ loss in weight [13]. Though reclaimed industrial wastewater are reported to be used in cement mortar for mixing, there is very tiny information is available on the permissible limit of heavy metals in mixing water and cement mortar made with heavy metal spiked de-ionized water exposed to acid attack, alkaline attack and sulphate attack. Hence, this exploration was carried out to understand the consequence of Chromium $(\mathrm{Cr})$ in mixing water on soundness, setting times, compressive strength, acid attack, alkaline attack, sulphate attack and chloride ion penetration on high performance cement mortar.

\section{MATERIALS AND METHODS}

The materials used in this investigation include:

1. 53 - Grade OPC

2. Fine aggregate ( Ennore sand - grade I, grade II and grade III)

3. Micro Silica

4. Water (De-ionized)

5. Super plasticizer

6. Heavy Metal (Chromium)

7. Chemicals

\subsection{Cement}

Ordinary Portland cement (53 Grade) was used for this study. Initial experiments like initial setting time, final setting, soundness and compressive strength test on mortar cubes were conducted. The physical and chemical properties of cement are within the permissible limits as per IS 12269:1987 and are given in Table 1 and Table 2 respectively.

Table 1: Physical Properties of Cement

\begin{tabular}{|c|c|c|}
\hline S. No. & Property & Result \\
\hline 1 & Specific gravity & 3.20 \\
\hline 2 & Fineness & $325 \mathrm{~m}^{2} / \mathrm{kg}$ \\
\hline 3 & Initial setting time & 150 minutes \\
\hline 4 & Final setting time & 260 minutes \\
\hline \multirow{4}{*}{5} & Compressive strength & $\mathrm{MPa}$ \\
\cline { 2 - 3 } 5 & a) 3 days & 29 \\
\cline { 2 - 3 } & b) 7 days & 38 \\
\cline { 2 - 3 } & c) 28 days & 54 \\
\hline 6 & Soundness & $0.5 \mathrm{~mm}$ \\
\hline
\end{tabular}

Table 2: Chemical Composition of OPC

\begin{tabular}{|c|c|c|}
\hline S.No. & Oxide Composition & Percent \\
\hline 1 & $\mathrm{CaO}$ & 64.58 \\
\hline 2 & $\mathrm{SiO}_{2}$ & 21.83 \\
\hline 3 & $\mathrm{Al}_{2} \mathrm{O}_{3}$ & 5.48 \\
\hline 4 & $\mathrm{Fe}_{2} \mathrm{O}_{3}$ & 4.46 \\
\hline 5 & $\mathrm{MgO}$ & 1.10 \\
\hline 6 & Alkalies $\left(\mathrm{Na}_{2} \mathrm{O}, \mathrm{K}_{2} \mathrm{O}\right)$ & 0.002 \\
\hline 7 & $\mathrm{SO}_{3}$ & 1.5 \\
\hline
\end{tabular}

\subsection{Fine Aggregate}

The fine aggregate used throughout this investigation was obtained from Ennore, Tamil Nadu minerals limited, Chennai. It is approved by Bureau of Indian Standards (BIS) to manufacture and supply of Indian Standard sand conforming to IS 650:1991. The physical and chemical properties of the sand are presented in Table 3 \& Table 4:

Table 3: Physical properties of Ennore Sand

\begin{tabular}{|c|c|}
\hline Physical property & Results \\
\hline Specific gravity & 2.64 \\
\hline Bulk density(kg/m3) & 15.54 \\
\hline Fineness modulus & 2.72 \\
\hline Particle size variation(mm) & 0.09 to 2 \\
\hline Color & Grayish white \\
\hline Water absorption in 24 hours & $0.8 \%$ \\
\hline Shape of grains & Sub angular \\
\hline
\end{tabular}

Table 4: Chemical properties of Ennore Sand

\begin{tabular}{|c|c|}
\hline Chemical Property & Results \\
\hline $\mathrm{SiO} 2$ & $99.30 \%$ \\
\hline $\mathrm{Fe} 2 \mathrm{O} 3$ & $0.10 \%$ \\
\hline Loss on ignition & $0.11 \%$ \\
\hline
\end{tabular}

\subsection{Micro Silica}

Micro silica used throughout this investigation was obtained from Mumbai, India. The physical and chemical properties of the Micro silica are presented in the Table 5 and Table 6. 
Ravi Sanker Reddy.B et al., International Journal of Emerging Trends in Engineering Research, 8(8), August 2020,4254 - 4261

Table 5: Physical Properties of Silica Fume

\begin{tabular}{|l|c|c|}
\hline \multirow{4}{*}{ Physical Properties } & Specific gravity & 2.22 \\
\cline { 2 - 3 } & Average particle size & 0.1 microns \\
\cline { 2 - 3 } & Bulk density & $223 \mathrm{~kg} / \mathrm{m}^{3}$ \\
\hline
\end{tabular}

Table 6: Chemical Properties of Silica Fume

\begin{tabular}{|c|c|}
\hline $\begin{array}{c}\text { Chemical } \\
\text { Compound }\end{array}$ & Percent of Total Weight \\
\hline $\mathrm{SiO}_{2}$ & 95.65 \\
\hline $\mathrm{Al}_{2} \mathrm{O}_{3}$ & 0.37 \\
\hline $\mathrm{Fe}_{2} \mathrm{O}_{3}$ & 0.21 \\
\hline $\mathrm{CaO}$ & 0.16 \\
\hline $\mathrm{MgO}$ & 0.09 \\
\hline $\mathrm{SO}_{3}$ & 0.42 \\
\hline $\mathrm{Na}_{2} \mathrm{O}$ & 0.51 \\
\hline Loss on ignition & 1.43 \\
\hline
\end{tabular}

\subsection{Water}

For reference specimens, De-ionized water was used and Chromium spiked de-ionized water was used for test specimens in different concentrations.

\subsection{Super Plasticizer}

Commercially available 'conplast SP-430' water reducing agent was used. The properties are given in the Table 7.

Table 7: Properties of conplast SP-430

\begin{tabular}{|c|c|}
\hline Property & Value \\
\hline Specific gravity & $1.20-1.22$ at $30^{\circ} \mathrm{c}$ \\
\hline Chloride & Nil as per IS: $9103-1999$ and BS : \\
content & 5075 \\
\hline Air entrainment & Approx. 1\% additional air over \\
& control \\
\hline
\end{tabular}

\subsection{Heavy Metal}

Chromium $(\mathrm{Cr})$ is a heavy metal with atomic number 24. It is slightly soluble in water. Chromium heavy metal introduced into the de-ionized water in predetermined concentrations such as 10, 50, 100, 500, 1000, 2000, 3000, 4000 and $5000 \mathrm{mg} / \mathrm{L}$. The physical properties of Chromium are presented in the Table 8.
Table 8: Physical properties of Chromium (Cr)

\begin{tabular}{|l|c|c|}
\hline \multirow{4}{*}{ Physical Properties } & Density & $2.87 \mathrm{gm} / \mathrm{cc}$ \\
\cline { 2 - 3 } & Melting point & $1152{ }^{\circ} \mathrm{C}$ \\
\cline { 2 - 3 } & Boiling point & $1300^{\circ} \mathrm{C}$ \\
\hline
\end{tabular}

\subsection{Chemicals}

2.7.1 Acids -Sulfuric acid of $2.5 \%$ concentration mixed in de-ionized water and Hydrochloric acid of $2.5 \%$ concentration mixed in de-ionized water.

2.7.2 Alkalies -Sodium hydroxide of $2.5 \%$ concentration mixed in de-ionized water.

2.7.3 Sulphates -Magnesium sulphate of $2.5 \%$ concentration mixed in de-ionized water.

2.7.4 Sodium Chloride $-3 \%$ by mass (reagent grade) mixed in de-ionized water.

2.7.5 Sodium Hydroxide - 0.3 N (reagent grade) mixed in de-ionized water.

\subsection{Methods}

The experimental methods adopted were in accordance with the standard procedures laid down in Bureau of Indian standards. Chromium was added into the de-ionized water in different concentrations such as $10 \mathrm{mg} / \mathrm{l}, 50 \mathrm{mg} / \mathrm{l}, 100 \mathrm{mg} / \mathrm{l}$, $500 \mathrm{mg} / \mathrm{l}, 1000 \mathrm{mg} / \mathrm{l}, 2000 \mathrm{mg} / \mathrm{l}, 3000 \mathrm{mg} / \mathrm{l}, 4000 \mathrm{mg} / \mathrm{l}$, and $5000 \mathrm{mg} / \mathrm{l}$. As per standard specification, Cement is replaced with silica fume [14]. As per literature, the concentrations of admixtures used are arrived at 9\% Micro Silica replacement in cement and addition of Super Plaster of $0.8 \%$ was fixed for reference high performance cement mortar specimens.

Seventeen reference mixes were cast for test and finally the test specimens were cast with (cement $+9 \% \mathrm{SF}+0.8 \% \mathrm{SP}$ ) based on maximum compressive strength. Chromium concentrations such as 10, 50, 100, 500, 1000, 2000, 3000, 4000 , and $5000 \mathrm{mg} / \mathrm{L}$ were introduced in de-ionized water as mixing water for test specimens. The physical properties obtained for reference specimens are given in Table 9.

Table 9: Physical properties of High performance

\begin{tabular}{|c|c|c|}
\hline \multicolumn{3}{|c}{ Cement mortar } \\
\hline 1 & Property & Result \\
\hline 2 & Initial setting time & 72 minutes \\
\hline \multirow{2}{*}{3} & Final setting time & 135 minutes \\
\cline { 2 - 3 } 3 & a) 3 days & MPa \\
\cline { 2 - 3 } & b) 7 days & 62 \\
\cline { 2 - 3 } & c) 28 days & 67 \\
\hline 4 & soundness & $1 \mathrm{~mm}$ \\
\hline
\end{tabular}


Ravi Sanker Reddy.B et al., International Journal of Emerging Trends in Engineering Research, 8(8), August 2020, 4254 - 4261

The amount of cement, fine aggregate and mixing waters for preparing each specimen were $200 \mathrm{gms}, 600 \mathrm{gms}$ and "(P/4) + 3 " where ' $\mathrm{P}$ ' denotes the percentage of mixing water required on combined weight of cement and fine aggregate to make a paste of standard consistency. Vicat's apparatus was used to find the Initial and final setting times[15]. As per IS 456-2000, to test the quality of water under question for its suitability to use for construction purpose, the compressive strength of the specimens made with water in question should not differ by 10 percent with that of the cubes made from de-ionized water. Also, if the difference in initial setting time of the sample under question is more than 30 minutes it is significant otherwise it is in significant. Le-Chatelier equipment was used to find the soundness of reference and test specimens. If the expansion of the sample is more than $10 \mathrm{~mm}$, it is significant otherwise it is insignificant.

The specimens were cast using standard metallic cube mould of size $70.6 \mathrm{~mm} \mathrm{X} 70.6 \mathrm{~mm}$ X $70.6 \mathrm{~mm}$ for compressive strength of cement mortar. The mix proportion of cement mortar that is cement to sand ratio is $1: 3$ by weight throughout [16]. The compressive strength of specimens was studied at different ages, i.e., 3 days, 7 days, 28 days, 90 days and 180 days[17]. The specimens in mould were maintained at a controlled temperature of $27^{\circ} \mathrm{c} \pm 2^{0} \mathrm{c}$ and at $90 \%$ relative humidity for 24 hours by covering the moulds with gunny bags wetted by the de-ionized water. After 24 hours specimens were de-molded and cured in de-ionized water for further 27 days. Three test specimens were tested for each mix and average of three values are taken to compare with reference specimens. The maximum Compressive strength was obtained at Chromium concentration of $5000 \mathrm{mg} / \mathrm{l}$. Hence the resistance to aggressive chemical nature was found at Chromium concentration of $5000 \mathrm{mg} / \mathrm{l}$.

In order to study the durability aspect, effects of acidic alkaline and sulfate were investigated. Solutions of Sulfuric acid, Hydrochloric acid, Sodium hydroxide and Magnesium sulphate were prepared with de-ionized water at $2.5 \%$ concentration in four non absorbent plastic tanks. Mortar cubes of $500 \mathrm{~mm}^{2}$ cross sectional area were cast and cured in the prepared solutions and tested for compressive strength and weight loss at 30 days, 60 days, 90 days and 180 days and it was compared with reference specimens cured in de-ionized water for the same period. The Chloride Ion Permeability was determined by using Rapid Chloride Permeability Test. Cylinders of dimensions $100 \mathrm{~mm}$ diameter and $200 \mathrm{~mm}$ height were cast and cured in water for 28 days.

By using the diamond saw, cut a $50 \mathrm{~mm}$ slice from the top of the cylinder so that cylinder specimen of size $100 \mathrm{~mm}$ in diameter and $50 \mathrm{~mm}$ in thickness was prepared and this specimen was used for Rapid Chloride Permeability test to determine the Chloride Ion Permeability. The diffusion cell consists of two chambers. $\mathrm{NaCl}$ solution concentration $2.4 \mathrm{M}$ was filled in one chamber and in another chamber $0.3 \mathrm{M} \mathrm{NaOH}$ solution was taken. This two component cell assembly checked for air and water tightness. Turn DC power supply on, set to $60 \mathrm{~V}$, and record initial current reading. During the test, the air temperature around the specimens shall be maintained in the range of 20 to $25^{\circ} \mathrm{C}$. Read and record current values at an interval of 30 minutes and monitored up to 6 hours. From the observed current values, the chloride ion permeability is calculated in terms of coulombs at the end of 6 hours by using the formula as given in ASTM C1202.

$\mathrm{Q}=900\left(\mathrm{I}_{0}+2 \mathrm{I}_{30}+2 \mathrm{I}_{60}+2 \mathrm{I}_{90}+\ldots .+2 \mathrm{I}_{300}+2 \mathrm{I}_{330}+\mathrm{I}_{360}\right)$

Where

$Q=$ Charge passed (Coulombs)

$I_{0}=$ Current immediately after voltage is applied in

Amperes,

$I_{t}=$ Current at ' $t$ ' minutes after voltage is applied in

Amperes,

\section{RESULTS AND DISCUSSIONS}

Effect of chromium metal present in mixing water on the properties of high performance cement mortar are analyzed by laboratory testing for respective parameters .They include setting times, soundness, compressive strength, acidic \& alkaline environment tests and rapid chloride permeability test.

\subsection{Effect on Setting Times}

The effect of Chromium present in different concentrations in the mixing water on setting times is represented graphically in Fig.1. It is observed that the initial and final setting process of cement got retarded with increase of Chromium concentration in de-ionized water.

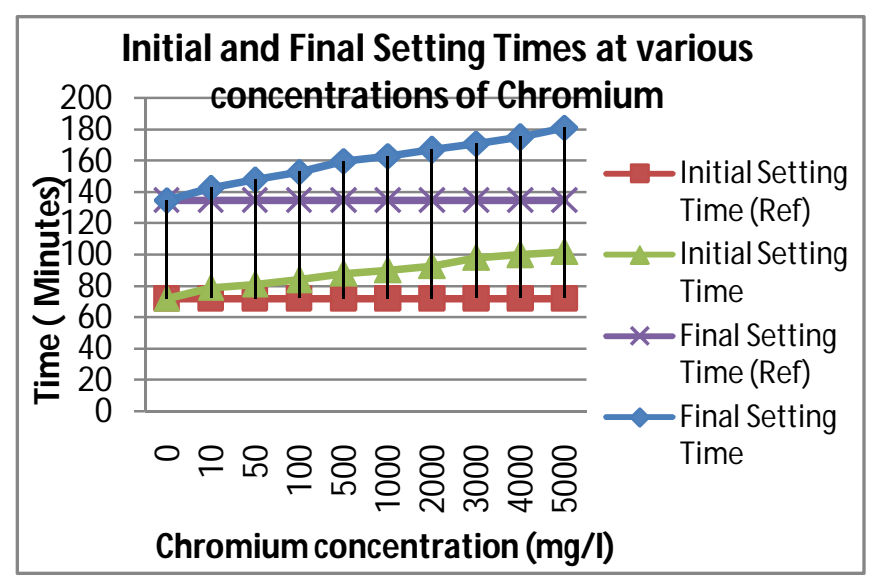

Figure 1: Variation of initial and final setting times of cement of various concentrations of Chromium

The increase in the initial setting time is insignificant at all concentrations of chromium (i.e. up to $5000 \mathrm{mg} / \mathrm{l}$ ), but the increase in the final setting times are insignificant up to 1000 $\mathrm{mg} / \mathrm{l}$ concentration and are significant at $2000 \mathrm{mg} / \mathrm{l}, 3000$ $\mathrm{mg} / \mathrm{l}, 4000 \mathrm{mg} / \mathrm{l}$ and $5000 \mathrm{mg} / \mathrm{l}$ concentrations of Chromium. The increase in the initial setting time is less than 30 minutes 
for all concentrations of chromium when compared with that of the test blocks made with de-ionized water.

The increase in the final setting time is 32 minutes at 2000 $\mathrm{mg} / \mathrm{L}, 36$ minutes at $3000 \mathrm{mg} / \mathrm{l}, 40$ minutes at $4000 \mathrm{mg} / \mathrm{L}$ and 46 minutes at $5000 \mathrm{mg} / \mathrm{l}$ concentration of chromium when compared with that of the test blocks made with de-ionized water, for all other concentrations it is less than 30 minutes. Hence, the effect of Chromium on an average over setting times is insignificant for all the specimens tested.

\subsection{Effect on Soundness}

The effect of Chromium on soundness of blended cement mortar is represented graphically in Figure2. The effect of Chromium at all concentrations on soundness of the cement was studied. The expansion after soundness test obtained with de-ionized water is $1 \mathrm{~mm}$.

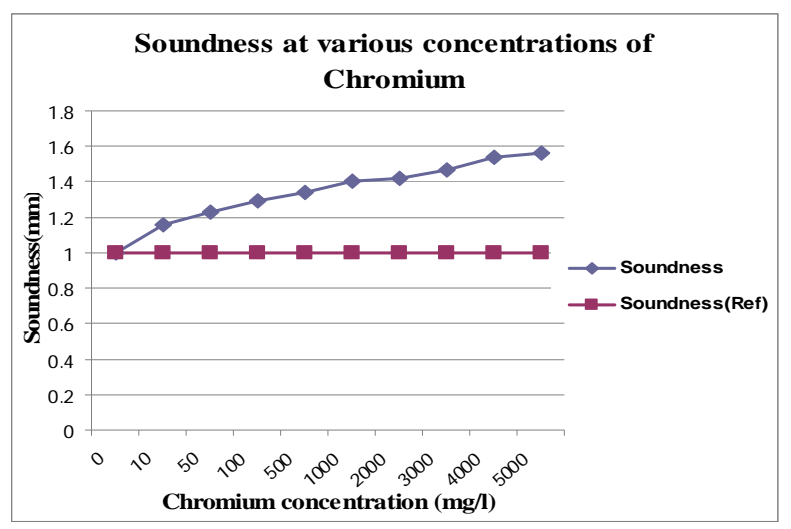

Figure 2: Soundness of specimens at various concentrations of Chromium

The same was obtained as $1.16 \mathrm{~mm}$ for $10 \mathrm{mg} / \mathrm{L}$ Chromium concentrated mixing water and $1.56 \mathrm{~mm}$ at $5000 \mathrm{mg} / \mathrm{L}$ Chromium concentrated mixing water. Expansion of cement mortar with all concentrations of Chromium is well within the prescribed limits. Therefore, the effect of Chromium metal present in mixing water for High performance cement mortar is insignificant.

\subsection{Effect on Compressive Strength}

The effect of Chromium present in mixing water at different concentrations on compressive strength of high performance cement mortar is graphically represented in Fig 3. Cement mortar cubes cast with chromium spiked de-ionized water for 7 Days, 28 Days and 180 Days of curing showed very slight decrease in compressive strength than that of controlled blended cement mortar cubes up to $50 \mathrm{mg} / \mathrm{l}$. Beyond $50 \mathrm{mg} / \mathrm{l}$ concentration of chromium, the compressive strength gradually increases and reaches maximum at $5000 \mathrm{mg} / \mathrm{l}$ concentration of Chromium. But for 3Days and 90 Days of curing showed gradual increase in compressive strength than that of controlled blended cement mortar cubes for all concentrations of Chromium.

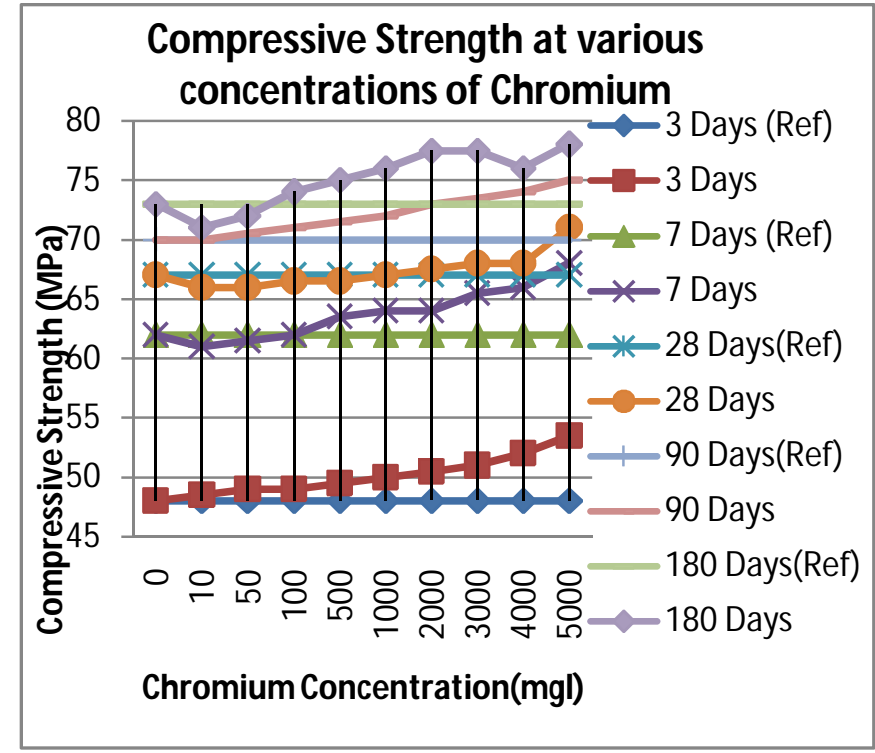

Figure 3: Compressive strengths of mortar cubes at various concentrations of Chromium at different ages

The percent change in compressive strength of blended cement mortar cubes cast with different concentrations of Chromium in de-ionized water was graphically represented in Fig 4. The percent change in compressive strength at all concentrations of Chromium is below 10 percent except at $5000 \mathrm{mg} / \mathrm{L}$ at 3 days when compared with that of the compressive strength of blended cement mortar cubes cast with de-ionized water. Hence, the effect of Chromium heavy metal on compressive strength up to $5000 \mathrm{mg} / \mathrm{L}$ is insignificant.

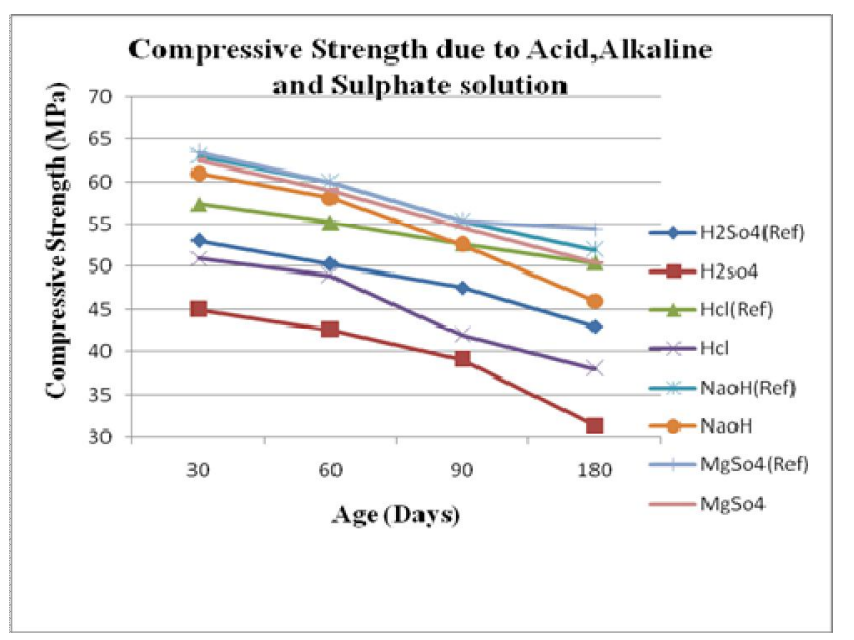

Figure 4: Percent change in compressive strengths at various concentrations of Chromium at different Ages

\subsection{Effect on Durability}

For conducting durability tests among the reference mix cubes made with de-ionized water, cement mortar cubes made with $5000 \mathrm{mg} / \mathrm{l}$ Chromium concentrated mixing water were taken for testing, at which the maximum compressive strength was attained. 


\subsubsection{Resistance against Acid Attack}

The compressive strength results and the loss in weight of the acid attacked blended cement mortar cubes cast with different mixing compounds in de-ionized water are graphically represented in Figure 5 and Figure 6.

\subsubsection{Resistance against Alkaline Attack}

The compressive strength results and the loss in weight of the alkaline attacked blended cement mortar cubes cast with different mixing compounds in de-ionized water and Chromium spiked de-ionized water are graphically represented in Figure 5 and Figure 6.

\subsubsection{Resistance against Sulphate Attack}

The compressive strength results and the loss in weight of the sulphate attacked blended cement mortar cubes cast with different mixing compounds in de-ionized water and Chromium spiked de-ionized water are graphically represented in Figure 5 and Figure 6.

The strength of the mortar cubes decreases with age. And also the strength changes with the change in curing solution. The lowest strength is observed for acid attack and less reduction in strength is observed for sulphate attack. The lowest strength is observed for the Sulfuric acid and then for hydrochloric acid and less reduction in strength is observed for Magnesium sulphate. Next to Magnesium sulphate, slight increase in strength is observed for alkaline solution

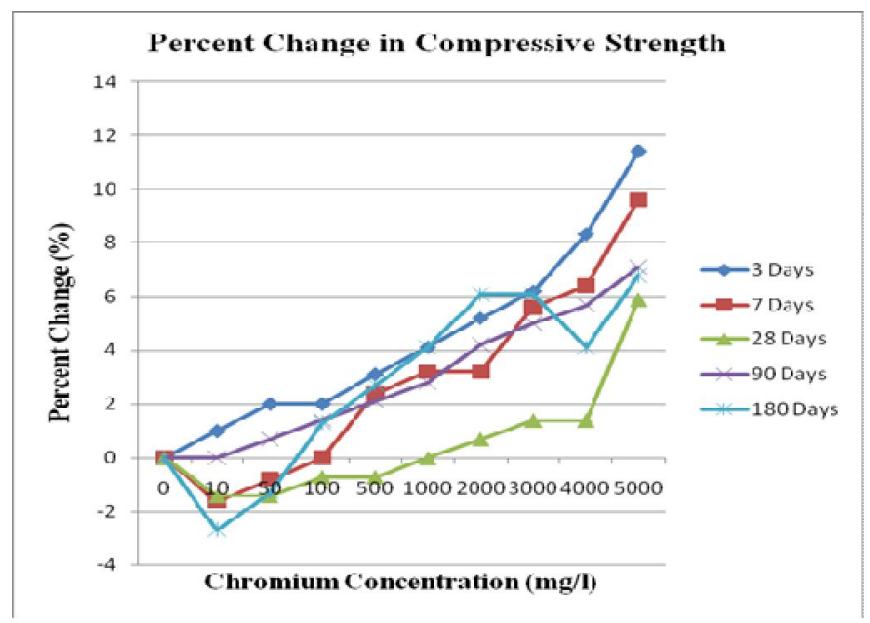

Figure 5: Compressive strength of control cement mortar cubes and that of cubes cast with Chromium containing water immersed in different solutions.

The change in the strength of the mortar cubes cast with Chromium when compared with control mortar increases as the age increases. And as the age increases, the change in the compressive strength decreases, it can be seen in Figure 5. The main reason is the surface of the cube erodes initially at higher rates and as the age increases the rate of erosion decreases slowly.
The percentage change in the compressive strength ranges from $36.6 \%$ at 30 days exposure to $55.7 \%$ at 180 days when exposure to Sulphuric acid. The percentage change in the compressive strength ranges from $28.1 \%$ at 30 days exposure to $46.4 \%$ at 180 days when exposure to Hydrochloric acid. The percentage change in the compressive strength ranges from $14 \%$ at 30 days exposure to $35.2 \%$ at 180 days when exposure to Alkaline media. The percentage change in the compressive strength ranges from $11.9 \%$ at 30 days exposure to $28.8 \%$ at 180 days when exposure to Sulphate media.

The weight loss of the blended Cement Mortar cubes cast with de-ionized water when immersed in acidic media is more and considerable and the same is negligible when exposed to Alkaline and Sulphate solutions. The maximum loss in weight was found to be at 180 days in acidic media.

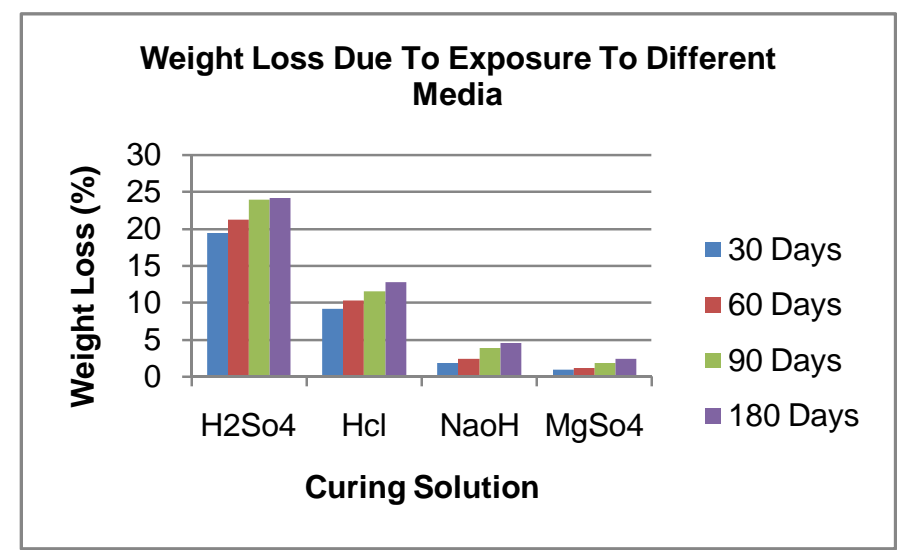

Figure 6: The graph showing the loss in weight of blended cement mortar cubes cast with water containing Chromium immersed in different solutions

The minimum loss in weight was found to be at 30 days in sulphate solution. This is due to the variation in $\mathrm{P}^{\mathrm{H}}$ values. The Figure 6 shows the loss of weight of blended cement mortar when immersed in different media.

\subsection{Rapid Chloride Permeability Test}

The values of ion penetration of the cylinder specimens cast with de-ionized water and Chromium spiked de-ionized water are graphically represented in Figure 7. The charge passing is less for the cylinder specimen cast without metal. The charge passing through the cylinders cast with Chromium is high when compare with that of the control mortar, as shown in Figure 7 . As per ASTM C1202 penetrating rate for both cylinder specimens cast with de-ionized water and Chromium spiked de-ionized water is categorized as low. 


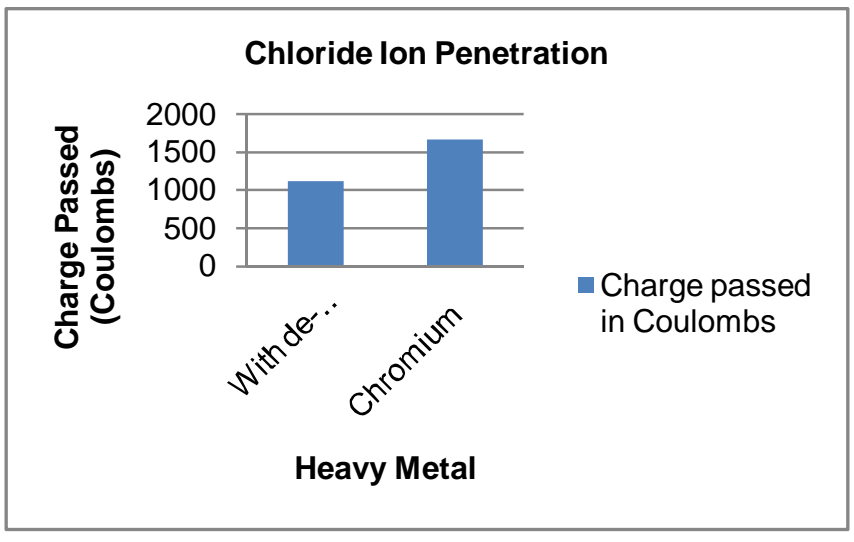

Figure 7: The graph showing the charge passed through the cement mortar specimens cast with De-ionized water and Chromium spiked De-ionized water

\section{CONCLUSIONS}

Based on the results and analysis of this investigation, The following conclusions may be drawn on the properties of High Performance Cement Mortar

1. As the chromium concentration in spiked water increased, the initial setting time of cement paste were retarded and is insignificant at all concentrations, the final setting time of cement paste were retarded and are insignificant up to $1000 \mathrm{mg} / \mathrm{l}$ and is significant beyond $1000 \mathrm{mg} / \mathrm{l}$.

2. Expansion of blended cement spiked with Chromium de-ionized water is well within limits at all concentrations.

3. As the chromium concentration in spiked water increased, gradual increase in Compressive strength was observed except at some concentrations of Chromium at 7 days, 28 days and 180 days of curing.

4. The blended cement mortar cubes cast with Chromium de-ionized water immersed in $\mathrm{H}_{2} \mathrm{So}_{4}, \mathrm{HCl}$ solutions showed more reduction in compressive strength than that of the controlled blended cement mortar and showed very less reduction in compressive strength than that of the controlled blended cement mortar cubes exposed to $\mathrm{NaOH}$ solution, $\mathrm{MgSo}_{4}$ solution. The reduction in compressive strength of the controlled blended cement mortar is significant at 30 days exposure to $\mathrm{H}_{2} \mathrm{So}_{4}, \mathrm{HCl}$ solutions and is insignificant for exposure to $\mathrm{NaOH}, \mathrm{MgSO}_{4}$ solutions.

5. Weight loss of the specimens is significant for the blended cement mortar cubes cast with Chromium spiked de-ionized water immersed in $\mathrm{H}_{2} \mathrm{SO}_{4}$ solution and it is insignificant for the blended cement mortar cubes cast with Chromium de-ionized water immersed in $\mathrm{HCl}$ solution up to 60 days beyond that it is significant. Weight loss is insignificant when the specimens were exposed to $\mathrm{NaOH}$ and $\mathrm{MgSO}_{4}$ solutions.
6. Permeability of blended cement mortar specimens cast with Chromium spiked de-ionized water is low.

7. The results obtained from this study indicates that industrial waste water containing Chromium up to concentration of $5000 \mathrm{mg} / \mathrm{l}$ has positive effect on engineering properties of High Performance Cement mortar and can be used as mixing water in High Performance Cement Mortar and the present investigation can be extended for concentrations of chromium above $5000 \mathrm{mg} / \mathrm{l}$.

8. High Performance cement mortar cast with Chromium spiked de-ionized water up to concentration of $5000 \mathrm{mg} / \mathrm{l}$ showed retarding nature and is suitable for hot weather condition to counter the rapid hardening due to high temperature.

9. In the present study, the effect of individual metals present in the waste water from electroplating industry is studied to find the properties of the High performance Cement Mortar. In the same way, the effect of other metals present in the waste water emerging from the other industries like steel, bewerages, textiles etc. can be used to find the properties of the High performance Cement Mortar. Not only the single metal but also the combination of the metals in the industrial waste water can be used to study further the properties of the High performance Cement Mortar.

\section{ACKNOWLEDGMENT}

The authors wish to thank Civil Engineering Department, S.V.U. College of Engineering, Sri Venkateswara University, Tirupati. This work was supported by providing resources like Digital Library and providing testing facilities.

\section{REFERENCES}

[1] Reddy Babu G, Sudarsana Rao H, and Reddy Ramana I.V. Use of Treated Industrial Waste water as Mixing Water in Cement Works, Nature Environment and Pollution Technology Journal, 6, 595-600 , (2007).

[2] Reddy Babu G, Sudarsana Rao H, and Reddy Ramana I.V. Effect of metal ions in industrial waste water on cement setting, strength development and hardening, The Indian concrete Journal, 83, 43-48, (2009).

[3] Tay J.H. and Yip W.K. Use of reclaimed wastewater for concrete mixing , ASCE, 113, 1156-1161, (1987).

[4] Reddy Babu G, Reddy B. Madhusudana, Ramana N. Venkata and Sashidhar C. Effect of Heavy metal and Magnesium Sulfate on Properties of Blended Cement Mortar, Research Journal of Chemical Sciences, Vol. 1(7), 27-32, Oct 2011.

[5] Tashiro C. Proceedings of the 7th International congress of chemistry of cement, Paris, 11, 11-37, (1980).

[6] Neville A. Water and concrete-A love-hate relationship - Point view, Concrete International, 22, 
Ravi Sanker Reddy.B et al., International Journal of Emerging Trends in Engineering Research, 8(8), August 2020,4254 - 4261

34-38, (2000).

[7] B. Rama Krishna, K. Harish Kumar, Mani Kumar and I. Likitha . Properties of GGBS Concrete Under Various Curing Conditions, International Journal of Emerging Trends in Engineering Research, Vol. 8, No. 4, pp. 1384-1387, April 2020. https://doi.org/10.30534/ijeter/2020/72842020

[8] David Darwin , Xiaofeng Cong, Shanglong Gong and Steven L. McCabe. Role Of Silica Fume In Compressive Strength Of Cement Paste, Mortar And Concrete, University Of Kansas Lawrence, Kansas, April 1990.

[9] Aitcin, P.C. Cements of yesterday and today: concrete of tomorrow, Cement and Concrete Research" 30 (9), 1349-1359, (2000). https://doi.org/10.1016/S0008-8846(00)00365-3

[10]Reddy Ramana I.V, Prasad Reddy N.R.S, Reddy Babu G and Kotaiah B. Effect of biological contaminated water on cement mortar properties, The Indian Concrete journal, 80, 13-19, (2006).

[11] Per Fidjestol et al., Guide for the use of silica fume in concrete, Reported by ACI committee, (2012).

[12]Turkel S, Felekoglu B and Dulluc S. Influence of various acids on the physico-mechanical properties of pozzolanic cement mortars, Sadhana Vol. 32, Part 6, pp. 683-691. (C) Printed in India, December 2007.

[13] Natesan S.C. and Karthikeyan Jaya Kumar. Mechanical Properties of High Performance Silica fume Concrete, 3rd International PCI/FHWA symposium on High performance concrete, Orlando, USA , (2003).

[14] ASTM C 1240-04, $2^{\text {nd }}$ Edition, Standard specification for silica fume used in cementitious mixtures.

[15] IS: 4031(part 4,5)-1998, Determination of consistency and setting time for cement paste.

[16] Mohd Fakri Muda, Saffuan Wan Ahmad, Fadhluhartini Muftah, Mohd Syahrul Hisyam Mohd Sani. Mechanical Behaviour of Mortar Made with Washed Bottom Ash as Sand Replacement, International Journal of Emerging Trends in Engineering Research, Vol. 7, No. 9, pp. 268-275, September 2019.

https://doi.org/10.30534/ijeter/2019/09792019

[17] IS: 4031(part 6)-1998, Determination of compressive strength for cement mortar cubes. 